\title{
Eva Verona, 1905-1996: An Appreciation
}

\section{Michael Carpenter}

E va Verona (Trieste, February 1, 1905Zagreb, May 19, 1996) was a Croatian librarian who, when she entered the international arena for the revision of cataloging rules, made many enduring contributions to the way we do things today.

Eva Verona's education was in physics and mathematics in the Faculty of Philosophy of the university in Zagreb. While a university student, she worked as a librarian in the Department of Surveying, developing a union catalog for Zagreb libraries of publications in physics and mathematics. This project later evolved into her first book, a 1941 list of library resources in Zagreb (Verona and MišicJambrišak 1941). After graduating from the university in 1929 , she started work in what was later to become the Croatian National and University Library. By the early 1950 s, she had become the head of two departments in that library-those for printed library materials and technical services-continuing until her retirement in 1967. Starting in 1966, she became a senior lecturer at the University of Zagreb and continued in this position well into the 1980s.

At the time of Verona's work, Croatia was a constituent unit of a federal state, Yugoslavia. Her work was not confined to the narrowness of a single constituent republic, for Verona became the founding chair of the Yugoslav Committee on Cataloging, which was established by the Union of Library Associations of Yugoslavia in 1961.

Verona made several scholarly contributions to English-language library literature, including articles on form headings
(Verona 1962), the early history of corporate entry (Verona 1956), and the distinction between literary units and bibliographical units (Verona 1959). The library resources she used in the composition of these articles are in a host of languages and must have come from a truly cosmopolitan collection of library literature. Today these studies are still marvels of clarity of exposition and contain excellent coverage of the relevant materials.

In these and other contributions, there are many references to Croatian cataloging practice, references that were to be systematized in her Croatian-language publications, in which Verona wrote what must be the most important core of that language's library literature. She wrote the two-volume Croatian cataloging code, one volume of which has appeared in two editions (Verona 1970-1983 and 1986), as well as a more scholarly treatment on the alphabetical catalog (Verona 1966 and 1971). The Croatian cataloging code was adopted by the library community in Yugoslavia as a whole. For many years, she was the chief editor of the journal Vjesnik bibliotekara Hrvatske [Bulletin of Croatian Librarians] (1950-) as well as a driving force in the Croatian library association, the Društvo bibliotekara Hrvatske.

According to Phyllis Richmond (1993), Verona first attended meetings of IFLA (International Federation of Library Associations) in 1952 and continued to do so for the next twenty-five years. Verona's work had its major effect on cataloging practice through her committee work in IFLA and work with IFLA-sponsored conferences. 
As chair of the Yugoslav Cataloging Committee, Verona was a delegate to the International Conference on Cataloguing Principles (the "Paris" conference) of 1961 as well as a contributor of a working paper for the conference. In this working paper, Verona set forth a cardinal point of Croatian cataloging practice, the use of added entry or reference cards for uniform titles rather than inserting them in the main entry.

The Croatian cataloging rules work in a card catalog environment, but unlike those that used to be prevalent in the United States, the card catalog envisioned in these rules does not rely as consistently on unit card technology. Occasionally added entries are abbreviated, often taking the form of references to the main entry.

In today's online environment, the controversy over whether uniform titles should be part of the main entry or an added entry might appear pointless, pertinent only to the card catalog environment. Such a conclusion would be mistaken: Imagine finding a uniform title for a translated work arranged under the heading for a translator or an illustrator. The uniform title in that context makes one think of the translator or illustrator as author of the work when that is manifestly not the case. Such situations can easily be found in some online catalog displays.

The position enunciated by Verona in her Paris conference paper is similar to that found in her "Literary versus Bibliographical Unit" cited above. In the Paris conference, she was opposed by Seymour Lubetzky, who thought it best to make uniform titles part of the main entry, a position that has been adopted by most cataloging agencies today.

What is probably Verona's most important achievement in international cataloging unification came about as the struggle over corporate entry played itself out among various cataloging agencies. Her contributions are found in two books, the first a commentary on the Paris Principles and the second a full-length study, Corporate Headings.

During the Paris conference, several delegations found themselves unable to accept the idea of corporate authorship. In an attempt to gloss over differences, the delegates established a subcommittee to redraft section 9 of the draft Statement of Principles, which dealt with corporate entry. The committee succeeded in its task by composing a new section with ambiguous wording, a situation that has resulted in the existence of two tendencies in post-Paris codes, one accepting the idea of corporate authorship and the other accepting corporate main entry only in certain limited circumstances. An example of each of these tendencies can be found by contrasting the 1967 version of the AngloAmerican Cataloging Rules and its acceptance of corporate authorship and the 1978 and 1988 versions of the same code, the Anglo-American Cataloguing Rules second edition (AACR2), with their denial of authorial status to corporate bodies.

With the possibility in mind of differing interpretations of the Statement Of Principles, which was supposed to unify international cataloging, the Paris conference decided that an annotated statement of principles should be issued. Although a preliminary edition was issued by $\mathbf{A}$. $\mathbf{H}$. Chaplin, it was deemed insufficient to deal with the needs of the profession. At the successor to the Paris conference, the International Meeting of Cataloguing Experts held in Copenhagen in 1969, it was decided to appoint a committee to provide a definitive annotated statement. Verona became the principal author of the new and final edition (Verona 1971). In addition to a historical commentary on the Paris principles, she also provided discussion and examples of how the principles are used in the various post-Paris codes. The most important chapter of the commentary relates to section 9 of the principles, that section dealing with corporate entry and in greatest need of reinterpretation. Here Verona documented the need for a new interpretation of section 9 , but ended up by concluding that rewriting might prove to be hopeless.

After the unsatisfactory attempt at reinterpretation of the Paris provisions for corporate entry in the commentary, Verona attended the 1972 Budapest IFLA conference and, after lengthy discussions 
with various delegations to the conference, agreed to undertake a new study of corporate headings (Anderson 1976), a study that would be published in 1975 as Corporate Headings. Verona elected to arrive at definitions of corporate bodies, corporate authorship, and corporate entries that followed a sort of common denominator approach, the common denominator being what all sides to the hotly disputed topic could agree upon. This approach, while not theoretically justifiable in and of itself, did bring a measure of international agreement on the subject.

On May 21, 1978, the Parliament of the Croatian Republic awarded Verona a Republic Medal for Life's Work. The citation mentions not only Verona's work on alphabetical cataloging theory, but also her work in the recovery of Croatian library materials that had been captured by other nations during World War II, work for which she had been previously honored with a Medal of Work with golden leaves by the republic's president. Additionally, she was honored for her work on both the current and retrospective Croatian national bibliographies (Gomerčić 1977-78).

Verona had to work in a multicultural environment within her home country, Yugoslavia, a country beset by differences in scripts for one common language (Serbian and Croatian are distinguished by the scripts in which they are written, Serbian being written in the Cyrillic and Croatian in the roman alphabet) and language differences among various parts of the country. When she began working in the international arena, she seemed admirably suited to bridging what appeared to be unbridgeable gaps in viewpoints, and her work is one of the reasons we can so easily speak about, and work with, international standards in cataloging today. This is no small achievement. I regret that I never met her but could only correspond with her.

It is perhaps worthwhile to remark that OCLC records no holdings in its member libraries for either the latest edition of Verona's Croatian cataloging code, or for her systematic treatise in Croatian on the subject. Verona's work in a multicultural environment, her multilingualism (including her limpid style in English), and the substantial nature of her contributions to our field should focus a grim light on our country's current lack of interest in international and comparative studies.

According to Mirna Willer (1996), a definitive bibliography of Verona's work should appear soon; an earlier version was published in 1986 (Horvat and Blažvić 1986). Other information on Eva Verona's activities up through 1967 is available in an anonymous article on her life and work published in 1968 ("Eva Verona" 1968).

\section{ACKNOWLEDGMENTS}

My thanks to Mirna Willer for sending me Horvat and Blažvic' (1986) and other materials. My thanks to my student Jovana Sušic' for translating "Eva Verona" (1968).

\section{WORKS CITED}

Anderson, Dorothy. 1976. "Margaret Mann Citation, 1976: Eva Verona." Library resources \& technical services 20: 373-76.

“Eva Verona: život i rad." 1968 . Vjesnik bibliotekara Hrvatske 14, broj 1/2: 5-8.

Gomerčic', Nada. 1977-78. "Eva Verona-Dobitnik Republicke nagrade za zivotno djelo." Vjesnik bibliotekara hroatske 23: 157-59.

Horvat, Aleksandra, and Dorica Blažević. 1986. Bibliografia radova dr. Eve Verone. Zagreb: Hrvatsko bibliotekarskodruštvo, Nacionalna i sveućilišna biblioteka.

Richmond, Phyllis A. 1993. Verona, Eva. World encyclopedia of library and information services. $3 \mathrm{~d}$ ed. Chicago: ALA, 854-55.

Verona, Eva. 1956. A historical approach to corporate entries. Libri 7: 1-40.

1959. Literary unit and bibliographical unit. Libri 9: 79-104.

1962. Form headings in catalogues of the past and present. Library resources $d$ technical services 6: 295-317.

- 1966. Abecedni katalog u teoriji $i$ praksi [The alphabetical catalog in theory and practice $]$. Zagreb.

—_. 1971. 2d enl. ed. izradbu abecednih kataloga [Code and manual for the production of the alphabetical catalog]. Društvo bibliotekara Hrvatske, Posebna izdanja. Zagreb, 
Društvo bibliotekara Hrvatske, 2 vols. - 1986. 2 d rev. ed. of vol. 1.

- 1971. Statement of principles adopted at the International Conference on Cataloguing Principles, Paris, October, 1961: Annotated edition with examples. London: IFLA Committee on Cataloguing.

1975. Corporate headings: Their use in library catalogues and national bibliog- raphies: A comparative and critical study. London: IFLA Committee on Cataloguing.

Verona, Eva, and Jelka Mišič-Jambrišak, comps. 1941. Knizznice u gradu Zagrebu; vodič $i$ popis casopisa koje navedene knjižnice primaju. Zagreb: Društvo hrvatskih srednjoskolskih profesora.

Willer, Mirna. 1996. Zagreb, National and University Library, personal communication August 22.

\section{INDEX TO ADVERTISERS}

ACRL

Baker \& Taylor

Blackwell

Gale Research

Kent Adhesive/Kapco

Library Technologies

OCLC

Readmore

Todd Enterprises 